\title{
LEGAL ISSUES IN PUPIL TRANSPORTATION
}

\author{
E. C. BOLMEIER*
}

Since pupil transportation has developed into one of the most important, costly, and hazardous of the auxiliary services of the schools, it is not surprising that it should be the subject of much legislation and frequent litigation. It is more surprising that this development has occurred within such a brief period of time. Fifty years ago the transportation of pupils at public expense was practically unheard of in most communities; only a minority of the states had meager legislation authorizing expenditure of public funds for pupil transportation; and very few cases dealing with pupil transportation found their way to the courts. In contrast, now nearly 7,500,000 elementary-and secondary-school pupils, or approximately 29 per cent of those enrolled, are transported to and from school at an annual cost of over $\$ 200,000,000$, paid for out of public funds; every state has detailed statutory provisions pertaining to many aspects of pupil transportation; and numerous cases concerning pupil transportation reach the higher state and federal courts every year.

The growth of litigation on pupil transportation is indicated by the number of higher court cases reported on the subject in the Decennial Digests. Only 2 cases were reported in the First Decennial Digest, I897-Ig06; I4, in the Second Decennial Digest, 1907-1916; 35, in the Third Decennial Digest, 1916-x926; 80, in the Fourth Decennial Digest, I926-1936; and 60, in the Fifth Decennial Digest, 1936-1946. On the basis of cases which have been and are being reported in the present decade, it is highly probable that the number of cases to be reported in the next Decennial Digest will be less than for the decade preceding.

It is significant to note that the peak in the number of court cases on pupil transportation was in the decade, r926-I936, even though the number of pupils being transported has grown continuously since that period. A decrease in litigation during a period of increasing transportational service may be partially due to greater clarity and specificity in statutory provisions authorizing pupil transportation at public expense. A more decisive factor, however, is probably a firmer establishment of legal principles pertaining to the subject. Court consistency in ruling on certain aspects of pupil transportation provides some degree of certainty which often makes further litigation unnecessary. Of course, due to changes in time and conditions, and the many variations in state constitutional and statutory provisions, there will no doubt continue to be a need for judicial clarification of the legal problems involved in pupil transportation.

No attempt will be made in this discussion to cover all the many legal aspects of pupil transportation. The scope of treatment will be limited to several areas in

- B.S. 1927, N.Dak. State College; M.A. r931, Ph.D. 1937, University of Chicago; Ass't Superintendent of City Schools, Jackson, Miss., 1940-1948; Director of Graduate Studies and Professor of Education (including School Law), Duke University. 
which litigation is most frequently involved, such as: (I) authorization to provide transportation for public school pupils; (2) authorization to provide transportation for parochial school pupils; and (3) liability for personal injuries incurred in pupil transportation. Reference will be made only to certain cases which illustrate well established legal principles.

Authorizatron to Provide Transportation for Public School Pupils

\section{A. Constitutionality of Transportation Legislation}

In some of the earlier cases, the constitutionality of legislation providing for pupil transportation was challenged on the grounds of discrimination, in that some pupils were transported at public expense while others were not. These allegations were so convincingly disproved in the beginning by the courts ${ }^{1}$ that the question has not been raised in recent decades. The established legal principle is that transportation laws are not discriminatory, nor do they violate uniformity of public school operation, because any child attending the public schools may bring himself within the scope of the transportation law by meeting specified standards. Of course, transportation laws, or any other laws, designed to favor special groups or classes of the population would meet with judicial disapproval.

\section{B. Implied and Express Authorization}

A more persistent question facing the courts in the early stages of pupil transportation had to do with the school district's power to provide transportation without express authorization to do so. Only in rare cases and under rather unusual circumstances has a court upheld implied authorization for school districts to provide transportation at public expense. ${ }^{2}$ In the great majority of cases, it has been held that in the absence of expressed statutory authorization to transport pupils to and from school no such authority can be implied. Even where the statute authorized the school board "to do all things needful and necessary for the maintenance, prosperity, and success of the schools of the district and the promotion of the thorough education of the children thereof," the court ruled that the district could not compel grant of state aid for expenditure of money for transportational services. ${ }^{3}$

The question as to whether or not school districts can legally provide pupil transportation without express statutory authorization to do so is no longer significant, for the simple reason that every state now has statutes authorizing the expenditure of public funds for the transportation of pupils. A more important question, at present, concerns the conditions under which a school district is compelled to provide transportation.

${ }^{1}$ Bufkin v. Mitchell, I06 Miss. 253, 63 So. 458 (1913); Cross v. Fisher, 232 Tenn. 31, 177 S.W. 43 (1915).

${ }^{2}$ Foster v. Board of Education, I3I Kan. I60, 289 Pac. 959 (1930); Dahl v. Independent School District No. 2, 45 S.D. 366, I87 N.W. 638 (1922); Malounek v. Highfill, I00 Fla. 1438, 131 So. 313 (1930).

${ }^{3}$ Township School District of Bates v. Elliott, 276 Mich. 575, 268 N.W. 744, 745 (x936). 
Due to the variations in statutory provisions no single answer could be given which would apply to all states, or even all districts within a single state. In some instances the law specifically requires a district to furnish free transportation; in other instances the law makes the furnishing of transportation optional with the school board; and in still other cases the duty is mandatory upon the board only under certain conditions.

I. Mandatory provisions. Under statutes where the duty to transport pupils to and from school is mandatory the law must be reasonably construed so that no child entitled to transportation will be denied the privilege. "No discretion is conferred upon the board to expand this delegation of power. The power actually conferred is extraordinary from any point of view. It has been carefully hedged about so as to forbid, rather than to invite, expansion."

Litigation has frequently developed where school boards have attempted to evade the statutory requirement of furnishing transportation to certain children because of the undue expense whch would be involved. Unless the statute specifically authorizes board discretion in such matters, the courts will not permit it. In an illustrative case ${ }^{5}$ a school board failed to provide transportation for a certain child because of the high cost involved in establishing a bus route for one child in an . isolated area. The board urged the parent to transport the child for compensation, which the parent refused to do. The court reasoned:

It is not a question of how much it will cost the district to transport this child or that child. The district has no right to say it will transport certain children but to transport the remainder will be too costly . . . it is no excuse that plaintiff refused to contract to convey his own children. There was no statutory duty compelling him to so contract.

In another case ${ }^{6}$ where a school district board failed to list in its budget under the transportation fund, or to include in its general fund, certain costs of transportation which could have been anticipated at the time when the budget was being adopted, the court ruled that this fact did not relieve the school board from its statutory liability to compensate persons for transporting children to school.

If the duty of a school board to provide transportation is a mandatory one, the board cannot deny certain children as much of the service as they wish to accept merely because they may not wish to accept all of what they are entitled to. For example, where children were entitled to transportation to the embarkation point for the school which the board designated for their attendance, the court decided that they were entitled to transportation to the same embarkation point even though they chose to proceed from the point to a school of their own choice. ${ }^{7}$

Transportation laws which are most mandatory on the part of local boards of education are those in which the state board of education is authorized by law to

\footnotetext{
"Schmidt v. Blair, 203 Iowa I016, I021, 213 N.W. 593, 595 (1927).

${ }^{5}$ Mumm v. Troy Township School District, 240 Iowa ro57, ro6r-1062, 38 N.W.2d 583, 585-586 (1949).

${ }^{\circ}$ Kimminau v. Common School District No. I, I70 Kan. 124, 223 P.2d 689 (1950).

${ }^{7}$ Alfred v. Shaw, 313 Ky. 80, 230 S.W.2d ro2 (I950).
} 
specify, within constitutional and legislative limitations, the regulations under which the transportation is to be provided. In at least five states (Delaware, Minnesota, New Mexico, New Jersey, and North Carolina), the state boards are so empowered. Although much of the authority may be discretionary for the state board of education, it is usually mandatory for the local boards. Any regulations which the local board of education may specify must conform to those of the state board of education. $^{8}$

2. Discretionary authority. In certain instances the law makes the furnishing of transportation optional with the local board of education. Although the entire area of pupil transportation may not fall within the discretionary authority of the local board, in approximately two-thirds of the states some degree of discretion is allowable. Frequently the law is mandatory with regard to certain pupils, permissive with regard to others, and silent with regard to the remainder.

Where the law is clear and specific in its delegation of discretionary authority to school boards for the furnishing of transportation, there is little need for litigation regarding the matter. If the board exercises its discretionary authority honestly, it will be upheld in court even though there is evidence that the board's action might not have been satisfactory or beneficial to certain residents of the school district. It is not likely that the courts will interfere unless there is evidence that the board acted in an arbitrary and capricious manner.

Numerous cases may be cited in which the courts have upheld the discretionary authority of school boards in furnishing or refusing to furnish transportation to certain pupils. For example, in the case of Pass vs. Pickens, where grammar school students in certain districts received transportation to and from the district school but where high school students, many of whom lived in the same residence with grammar school students, were given bus transportation to a certain independent school, a denial by the county board of education of bus transportation to grammar school students who desired to attend the independent school, was not, in the opinion of the Supreme Court of Georgia, an abuse of discretion despite the claim that such students would be deprived of greater educational advantages. In the words of the court, "to force the defendants to do so by compulsory process of the court would be a distinct usurpation by the court of the judgment and discretion of the board of education vested in them by law."

In another case ${ }^{10}$ where there was involved action of the school district in closing a white school and transporting the district's grade school white children to another district while keeping three Negro schools open, this was held by the court not beyond the statutory powers of the school board and not an abuse of discretion. A declaration of the court regarding this case is significant in that it is a clear-cut statement of legal principle:

\footnotetext{
${ }^{8}$ Rankin v. Board of Education, I35 N.J.L. 299, 5I A.2d I94 (1947).

${ }_{204}$ Ga. 629, 632, 5r S.E.2d 405, 407 (I949).

${ }^{10}$ White v. Jenkins, 213 Ark. I19, 121, 209 S.W.2d 457, 458 (1948).
} 
It is well settled that courts may not intervene to control matters in the discretion of administrative bodies such as school boards in the absence of a showing of an abuse of such discretion. Necessarily, some latitude in the exercise of this discretion must be given to these boards. They represent the people of the locality affected and naturally are closer to the problems to be solved than any court or other agency could be.

In a case ${ }^{11}$ where it was evident that a school board exercised discretion honestly in preparing a school bus schedule for transportation of pupils but unintentional discrimination resulted, the bus schedule prepared by the board was held legally proper, After finding that "the directors were doing the best they could with what they had, under the circumstances," the Supreme Court of Arkansas ruled that "their [the board's] discretion which is being honestly exercised should not be interfered with, although equal facilities are not furnished all the children in the district. ...."

Even if a school district has, in previous years, provided transportation it may discontinue the service within the discretionary authority delegated to it. In a Minnesota case $^{12}$ it was revealed that for twelve consecutive years the school district provided free bus transportation for pupils, but then beginning with the I945-46 school year it discontinued the service. In upholding the board's action, the court ruled that "the fact that the electors voted in favor of free transportation of pupils upon such an unauthorized submission of the question to them was not controlling and binding on defendant. ..."

In some instances the school board's interpretation of certain words or clauses within a statute falls within the board's discretion on transportational problems. For example, in a North Dakota case, ${ }^{13}$ when a statute authorized a school district to pay a transportation allowance to each family living a certain distance from the school district, the words "to each family" were construed by the board, and found by the court, not to mean "to every family." Therefore, the school board's discretion to pay some patrons according to number of miles traveled and to furnish to other patrons vehicular transportation or its equivalent was held legal.

Many laws place distance limitations on the furnishing of pupil transportation. Although most of such laws specify "two miles" as the distance limitation, there are variations. For example, Indiana makes transportation of pupils aged 6 to 12 mandatory if they live at least five-eights of a mile from school, whereas Washington permits transportation to union high schools only if the pupils live four miles from school. ${ }^{14}$

Where the distance limitation is specified in terms of miles, the school board's authority to furnish transportation is accordingly limited and decisive. Arriving at a decision is more difficult when the distance limitation is stated in such vague terms as "unreasonable," "remote," or "inaccessible." In the several states where no definite

${ }^{11}$ Woodlawn School District No. 6 v. Brown, 216 Ark. 1417 , 223 S.W.2d 818, 819 (1949).

${ }^{10}$ Muehring v. School District No. $3 \mathrm{I}$ of Stearns County, 224 Minn. 432, 438, 28 N.W.2d 655, 659 (1947).

${ }_{13}$ Reich v. Dietz School District No. $x 6$ of Grant County, 55 N.W.2d 638, 641-642 (N.D. 1952).

14 Madaline Kinter Remmenin, The Law of Local Public School Administration 14i (I953). 
distance limitation, in terms of miles, has been placed on pupil transportation, the board's decisions in determining what is "reasonable" or "unreasonable" have been challenged frequently in the courts as abuses of discretion. In all cases the decisions have been based upon a composite of existing factors rather than upon the single one of distance. The school board as well as the court takes into consideration such factors as age of the children to be transported, climate, width and surface of the passageway, traffic hazards, amount of traffic, and even the acquaintance and experience of the children with traffic situations.

Three illustrative court cases, all in the state of Kentucky, where the law makes mandatory the furnishing of transportation to elementary pupils "who do not reside within reasonable walking distance of the school provided for them," reflect the emphasis given by the courts to certain factors which should enter into the board's exercise of discretionary authority.

In the first case, ${ }^{15}$ the Court of Appeals found that "these young children were walking distances of 2 to 3 miles [on a] tortuous road presenting a possible peril upon its pedestrians, particularly little children, in almost every furlong of its length. This road has neither sidewalks nor graveled berm. This route is one of heavy travel, both by trucks and other vehicles. This route crosses a narrow bridge, a railroad, a federal highway where fast-moving traffic continually chants a funeral dirge for the unwary." The court believed such hazards and highway conditions were more decisive than the distance involved, and so ruled that "appellants abused their discretion in deciding that appellees' children are within a reasonable walking distance of their school."

In a later case, ${ }^{16}$ the Court of Appeals found that traffic conditions for children were rather treacherous. The road was quite narrow, and at places had no shoulder or berm. There was no walkway along it, and in a few places the road had fairly steep banks. Nevertheless, because of the lesser degree of danger which existed in this case as compared with the previous one, the court did not think that the board acted "in an arbitrary and unreasonable manner in refusing to furnish transportation for the children involved in this case."

In the latest case in point, ${ }^{17}$ the Court of Appeals upheld the action of a board in refusing to transport children over a highway with heavy traffic and numerous hazards. The decision was based, however, on existing factors quite different from those considered in the two previous cases. In its opinion the court declared that:

In a suburban area, such as this, children are exposed to the hazards of traffic in any of their outdoor activities. They will be upon the streets in play, in visiting their friends, and in going to the stores. They early in life must be trained to take care of themselves in traffic.

Then after contrasting the suburban child's familiarity with traffic situations with

\footnotetext{
${ }^{15}$ Schmidt v. Payne, 304 Ky. 58, 6r, 199 S.W.2d 990, 99r, 992 (1947).

${ }^{18}$ Board of Education of Clay County v. Bowling, 312 Ky. 749, 229 S.W.2d 769, 77x (1950).

${ }^{17}$ Bowen v. Meyer, 255 S.W.2d 490, 49r (Ky. 1953).
} 
that of the rural child, the court ruled that "the hazards presented are not of such magnitude as to make it mandatory upon the board to furnish transportation."

II

\section{Authorization to Provide Transportation for Parochial School Pupils}

The legal question pertaining to transportation of parochial school pupils is quite different from that of transporting public school pupils. The former is based primarily upon the constitutionality of legislation designed to expend public funds for sectarian purposes, whereas the latter concerns mainly legislative intent in the degree of discretionary authority delegated to local boards of education.

Virtually every state has a provision in its constitution prohibiting the appropriation of public funds for religious purposes. Nevertheless, such constitutional provisions have not always been interpreted by certain legislatures and some of the courts as prohibiting the expenditure of public funds for the transportation of children to parochial schools.

Numerous statutory provisions frequently permit, with judicial sanction, the expenditure of public funds which-even though not construed to benefit sectarian schools-do benefit pupils attending such schools. The extent to which the "child benefit theory" may be applied in the expenditure of public funds for the transportation and other services and costs of children attending nonpublic schools is a question with which the courts have struggled for years and will, in all probability, struggle for many years to come.

So far the higher courts have handed down decisions in more than a dozen cases in which the legality of providing transportation of parochial pupils at public expense has been challenged. In the early cases, the courts declared such practices illegal because of constitutional violations. Even in later cases, where the majority opinions uphold the constitutionality of the statutes authorizing free transportation of parochial pupils, strong dissenting opinions often accompany the decisions.

An early Wisconsin case ${ }^{18}$ involved the right of a school board, in the absence of a statute permitting it to do so, to provide transportation for parochial pupils. In ruling that the whole scope and purpose of the statute is to comply with the constitutional mandate requiring free nonsectarian instruction, the court declared that: "The board is not authorized to expend public funds for any other purpose. The contract made by the district board whereby it attempted to provide transportation of pupils to a private school was an act beyond its authority and therefore invalid."

The leading case for the early period, however, was in New York. ${ }^{10}$ Here the court ruled emphatically that free transportation of pupils to nonpublic schools was an "indirect" aid to denominational schools and therefore unconstitutional.

In the same year that the New York court ruled against free transportation to

${ }^{18}$ State ex rel. Van Straten v. Milquet, 180 Wis. I09, II5-II6, I92 N.W. 392, 395 (r923).

${ }^{10}$ Judd v. Board of Education of Union Free School District No. 2, 278 N.Y. 200, 15 N.E.2d 576 (1938). 
parochial pupils, the first contrasting opinion was expressed in a Maryland case." In this case it was agreed that free transportation to parochial pupils might have been an aid to the school, but not in sufficient degree to prohibit the legislature from providing necessary transportation to parochial pupils.

The twist in the Maryland case apparently established a precedent for other courts to follow, even on the opposite coast. This was evidenced by the ruling of a California court. ${ }^{21}$ Despite a provision in the California Constitution that: "No public money shall ever be appropriated for the support of any sectarian or denominational school,"22 free transportation was allowed parochial pupils where the public-school buses were not filled and where the additional parochial pupils to be transported did not crowd the buses already being used. The court cited other leading cases which support the theory that "where the main purpose of an enactment is lawful, and an incidental or immaterial benefit results to some persons or organization, which benefit is not directly permitted by law, this incidental benefit alone will not defeat the legislation, its main purpose being lawful."

It was in this case that the court also stressed the point that "no one has yet challenged the right of any law abiding citizen to travel to a school over a highway built with public funds because of his religious beliefs or because he is attending a denominational institution. ...."

It was with this background of conflicting opinions of state courts that the United States Supreme Court, in a five-to-four decision, upheld the first school bus case to reach it. ${ }^{23}$ The Court declared constitutional a New Jersey state law which provided for the transportation of parochial school children at public expense. The Court ruled that the New Jersey statute violated neither the "due process" clause of the Fourteenth Amendment nor the First Amendment by giving support to a religious establishment by paying for the transportation of pupils to parochial schools.

The United States Supreme Court decision was not to be interpreted as sanctioning the expenditure of public funds for the transportation of parochial pupils without explicit provisions in the statute to do so. For example, in the very year the Everson case was decided, the Supreme Court of Pennsylvania refused a mandamus order that a Board of School Directors be compelled to furnish free transportation to a child attending a parochial school. In this case $\mathrm{s}^{24}$ the court held that the statute stipulating that the board may, out of funds of the school district, provide free transportation for any pupil to and from "public schools" authorized only the transportation of "public school pupils" and not "parochial school pupils."

Similarly, the Supreme Court of Washington interpreted a statute which provided for transportation to "all children" as applicable to "all children in public schools" only and not to "children attending a parochial school."25 The majority

\footnotetext{
${ }^{20}$ Board of Education of Baltimore County v. Wheat, 174 Md. 314, I99 Atl. 628 (1938).

${ }^{21}$ Bowker v. Baker, 73 Cal.App.2d 653, 658, 666, 167 P.2d 256, 261, 262 (1946).

22 Cal. Const. Art. IX, $\$ 8$.

${ }^{23}$ Everson v. Board of Education of Ewing Township, 330 U.S. I (I947).

${ }^{24}$ Connell v. Board of School Directors, $356 \mathrm{~Pa} .585,52 \mathrm{A.2d} 645$ (I947).

${ }^{25}$ Visser v. Noonsack Valley District No. 506, 33 Wash.2d 699, 207 P.2d I98 (1949).
} 
opinion in this case emphasized the fact that free transportation of children to parochial schools constitutes financial support for a "religious establishment" which is a violation of the state constitution.

Judging by the paucity of recent litigation on the issue, the legality of transporting pupils to parochial schools at public expense seems to be settled-at least for the time being. Since the United States Supreme Court ruled that the practice does not violate the First Amendment or the Fourteenth Amendment to the Federal Constitution, the individual states apparently have the right to control the matter by constitutional and statutory provisions. This is evidenced by the fact that the constitutional limitation, which formed the basis for the ruling against free transportation to parochial schools in an earlier New York case, ${ }^{26}$ was removed by the adoption of a constitutional amendment ${ }^{27}$ which permits the legislature to provide such transportation. Consequently, the action of the Acting Commissioner of Education was upheld in directing a board of education to provide transportation for pupils residing within the district to the nearest school. ${ }^{28}$

\section{III}

\section{Liability for Personal Injuries Incurred in Pupil Transportation}

The most fertile area for litigation in the field of pupil transportation has to do with liability. Although the total number of court cases on pupil transportation has been declining in recent decades, there has been an increase in the number of liability cases for the same period. This is due, in part, to the fact that states have been slow to enact legislation which clearly allocates responsibility when pupils and others are injured in the process of pupil transportation.

In virtually all cases it may be noted that plaintiffs bring action against several different parties, when damages are sought, with the apparent hope that there will be legal recourse from at least one of the parties involved. It then becomes the responsibility of the court to determine liability on the basis of evidence produced amid a hodgepodge of constitutional and statutory provisions.

\section{A. District Liability}

On the basis of common law, school districts (school boards), as agents of the state, cannot be held liable for the tortious acts of their officers and employees. Since school districts are creatures of the state and perform a governmental function, they are no more liable than the state itself. The courts have repeatedly and consistently applied the rule of nonliability to school districts on the ground that the school district is an instrumentality of the state in performing the governmental function of transporting pupils to and from school.

In virtually every court case involving liability for personal injury accruing from the negligent act of an employee, the court rules out liability of the school district

\footnotetext{
${ }^{23}$ Judd v. Board of Education, 278 N.Y. 200, I5 N.E.2d 576 (1938).

${ }^{27}$ N.Y. CONST. Art. II, $\$ 4$.

${ }^{28}$ Application of Board of Education, I99 Misc. 63I, x06 N.Y.S.2d 615 (Sup. Ct. I95I).
} 
unless there is a specific statute indicating that the school district shall assume such liability. A statement from the most recent case on pupil transportation reported at the time of this writing is typical: "A county board of education is not a corporate body with power to sue and be sued ... but is merely the agency through which the county, as a subdivision of the State, acts in school matters; and, when the members of the board of education, acting as such board, act upon matters lawfully within the jurisdiction of the board, it is the county acting through 'its corporate authority'...."29

Due to the injustice to injured parties of not being able to recover damages for injuries caused by negligence of school employees because (I) of district immunity from liability, and (2) of inability of other parties to pay damages, some states have enacted legislation designed to abrogate the immunity rule, and thereby permit school districts to be held liable for negligently caused injuries.

Several states (California, Washington, and New York) have, by statutory provisions, removed their school district privileges of immunity. Therefore if a pupil in any of those states is injured in the process of transportation to and from school, action may be brought against the school district to recover damages.

Because of the recent origin of the abrogation of immunity, there has not been much litigation involving the liability of school districts for transportational injuries. Nevertheless, in at least one case ${ }^{30}$ action was brought against a school district to recover damages for the death of a twelve-year-old boy killed by a school bus when it backed upon school property where the child and other pupils of the school were waiting to board buses. The court ruled that the school district "was negligent in failing to provide supervision of pupils while awaiting the school buses on the school grounds . . . and in failing to promulgate and enforce rules and regulations for their safety while so waiting." The district was held liable,

In addition to the three states which have waived their immunity from liability for all tortious acts committed by school employees, several states have in recent years attempted to waive their immunity as applied to certain aspects of pupil transportation. A North Carolina act which became effective July r, r953 is illustrative: $:^{31}$

Any county board of education or the board of trustees of any city administrative school unit, by securing liability insurance, as hereinafter provided, is hereby authorized and empowered to waive its governmental immunity from liability for any damage by reason of death, or injury to person or property, proximately caused by the negligent operation of any activity school bus....

\section{B. Driver Liability}

The driver of a bus is not immune from liability by virtue of the fact that the school district is immune. This was illustrated in a North Carolina case ${ }^{32}$ where a

${ }^{29}$ Krasner v. Harper, 82 S.E.2d 267, 272 (Ga. Ct. App. 1954).

${ }^{30}$ Barth v. Central School District No. I, 278 App. Div. 585, 102 N.Y.S.2d 263, 265 (2d Dep't I95I).

${ }^{31}$ N.C. GeN. STAT. \$115-45.I (1953 Supp.).

${ }^{32}$ Hansley v. Tilton, 234 N.C. $3,8,65$ S.E.2d 300, 303 (I95I). 
driver of a bus contended that since the school district was not liable for injuries growing out of the negligence of officers, agents, or employees, he, as an employee of the district, was also clothed with governmental immunity and exempt from liability. As in other similar cases the court denied such reasoning and stated:

Undoubtedly the county board of education, as an agency or instrumentality of the State, enjoys immunity to liability for injury or loss resulting from the negligence of the driver of its school bus. ... But the driver of the school bus, who is a mere employee performing a mechanical task, is personally liable for his own actionable negligence.

A school bus driver is not necessarily free from liability in bus accidents merely because of exercising ordinary care. The courts have repeatedly ruled that unless "extreme" and "extraordinary" care is exercised the driver may be held liable. Regardless of whether the driver is a "common carrier" or "private carrier" this legal principle prevails. For example, in an applicable Illinois case ${ }^{33}$ the court explained that "we do not deem it to be controlling whether the defendant was a common carrier or a private carrier, for it is our opinion from the facts in this case that it was the duty of the defendant to operate the bus with the highest degree of care consistent with the practical operation of the bus."

Liability for failure of bus drivers to exercise extreme care while transporting pupils is illustrated in a recent Georgia case ${ }^{34}$ where a bus driver was driving a bus load of children at a moderate rate of speed with the bus windows open. A protruding limb of a tree hit a child in the bus and put out his eye. In affirming the judgment of a lower court in favor of the plaintiff, the court stated in the syllabus:

An operator of a bus transporting children to and from school is a common carrier. His duty is to exercise extraordinary care for the safety of the passengers. Where ... the evidence authorizes the jury to find that the operator did not ... exercise such degree of care as the law imposed, such operator becomes responsible in damages for the injuries received by the passengers.

The liability of a school bus driver is not limited to the manner in which the bus is driven. $\mathrm{He}$ is also liable for damages resulting from injury of the children caused by unsupervised conduct in the bus. In a case ${ }^{35}$ where a child's eye was injured by a paper clip propelled by a rubber band in the hands of a boy being transported, the bus driver was held liable for not having maintained proper conduct in the bus.

In numerous instances the school bus operator has been held liable for a child's injury occurring after having left the bus. For example, in North Carolina the rules of the State Board of Education expressly provide that the driver must "supervise the activities of children discharged from the bus until they have crossed the highway in safety or are otherwise out of danger" and that he "shall not start the school bus until pupils are seen to be out of danger." A driver disregarded the reg-

${ }^{33}$ Van Cleave v. Illini Coach Co., 344 Ill.App. I27, x29, I00 N.E.2d 398, 399 (I95x).

${ }^{34}$ Eason v. Crews, 88 Ga. App. 602, 77 S.E.2d 245,246 (1953).

${ }^{35}$ Maley v. Children's Bus Service, II7 N.Y.S.2d 888 (Sup.Ct. x952). 
ulations, with the consequence that a school child, after leaving the bus, started across the road in front of it and was hit by it and fatally injured. The Industrial Commission, which is vested with authority to hear claims, found the driver guilty of negligence which was the proximate cause of the accident. In upholding the Commission's decision, the Supreme Court stated that "his [the bus driver's] passengers are in his care and he knows many of them must cross the road after they alight from the bus. It is his duty to see that those who do alight are in places of safety before he again puts his vehicle in motion." ${ }^{38}$

The Supreme Court of Wisconsin pointed out that a school bus driver has a duty to a pupil passenger "to provide a safe place to alight and ... to permit her to reach a place of safety before starting up the vehicle."37 In another instance a nine-year old boy was permitted to alight from the bus into a heavily traveled highway where he was hit and seriously injured. The court emphasized that "whether or not a place of deposit is a place of safety cannot be determined solely by whether or not one would be safe if he remained on the spot." ${ }^{38}$

The cases cited thus far are illustrative but by no means exhaustive in determining who is liable for injuries incurred in pupil transportation. Just one more case may be cited by way of summarizing the allocation of liability when a pupil is injured in the process of transportation. In this case ${ }^{39}$ four different parties were charged with liability when a motorist, in passing a parked school bus, struck a seven-yearold girl as she was crossing the street after alighting from the bus. In allocating liability for damages, the Court of Appeals of Louisiana reasoned: (I) A school district is an agent of the State and is not liable for torts committed by its trustees as employees, in absence of a statute imposing such liability. Therefore the school board was not liable. (2) Under a policy written for the school board, damages resulting from school buildings were covered but not those from buses or other vehicles, and therefore the insurer was not liable. (It was merely the limited terms of the insurance contract which released the insurer from liability.) (3) The failure of the school bus driver to warn the child was a breach of the driver's duty as a carrier. He, therefore, was liable. (4) Where a school bus, having all the physical characteristics of a school bus, was stopped beside the road with other vehicles stopped behind it, a motorist was negligent in passing the school bus and therefore was liable for injuries inflicted upon the student. Consequently, the Louisiana Court of Appeals rendered a judgment against the bus driver and the motorist.

\section{Liability Insurance}

Due to the fact that in forty-five states the school district cannot be held liable for injuries growing out of the negligence of its employees, and that frequently the employees are financially unable to pay the damages resulting from their negligent

\footnotetext{
${ }^{30}$ Greene v. Mitchell County Board of Education, 237 N.C. 336, 340, 75 S.E.2d 129, I3I (1953).

${ }^{37}$ Lempke v. Cummings, 253 Wis. 570, 572, 34 N.W.2d 673, 674 (1948).

${ }^{88}$ Davidson v. Horne, 86 Ga.App. 220, 226, 71 S.E.2d 464, 468-469 (1952).

${ }^{39}$ Mire v. Lafourche Parish School Board, 62 So.2d 541 (La. I953).
} 
acts, some legislatures have attempted to protect innocent school children and their parents by insuring against liability.

Insurance against liability, however, meets with numerous legal obstacles. Because the district is without liability, the courts have generally held that it is without power to spend public funds for liability insurance unless a statute permits it. To spend funds in such a manner, it is held, is not only a waste of public funds but an illegal expenditure as well. Protection against a loss for which there can be no district liability is unnecessary.

The position of the school district with respect to liability for personal injuries or property damages incurred in pupil transportation because of special legislation relating to liability insurance is far from clear in many states. So many differences in legislative enactments and legal interpretations within the different states prevail that there can scarcely be said to be any general trend or common practice. In some states school money cannot be used legally to purchase liability insurance; in others the law requires that such insurance be purchased; while in others it is a matter of local option. Some states have enacted legislation of a permissive type authorizing the use of school money for the purchase of liability insurance for pupil transportation but at the same time have sought to maintain the position of district immunity.

Where the legislature authorizes the school district to purchase liability insurance, the district does not necessarily waive its immunity. Moreover, the driver of a school bus is not immune from liability merely because the district purchases liability insurance against bus accidents. If a jury finds the bus driver negligent, the plaintiff may recover to the extent of the insurance coverage. If, however, the verdict exceeds the insurance coverage, the plaintiff has no redress against the school district to recover the remainder. ${ }^{40}$

In Georgia the school board is authorized and required by state law to cause policies of insurance to be issued insuring the children riding in the buses as well as the general public against death, bodily injury and property damage resulting from accidents in which buses are involved. In a recent case ${ }^{41}$ the Court of Appeals of Georgia quoted the statute that "nothing ... in this law shall be construed as imposing legal liability upon such boards on account of such accidents.... Wherever an insurance company issues a policy containing such a provision, the company shall not be estopped to deny its liability thereunder on account of the nonliability of said board."

\section{Conceusions}

It may be concluded from the foregoing that much of the litigation on pupil transportation is caused by the inadequacy and ambiguity of statutory provisions. In view of the fact that pupil transportation constitutes such an important, costly, and hazardous public enterprise it would seem that legislatures would do well to

${ }^{10}$ Rittmiller v. School District No. 84, I04 F. Supp. I87 (D. Minn. I952).

"1 Krasner v. Harper, 82 S.E.2d 267, 273 (Ga. Ct. App. r954). 
make a thorough appraisal of their pupil transportation laws to determine wherein improvements might be made. The litigated questions should indicate the points on which existing laws are unsatisfactory and vague.

Considerable litigation would be avoided if provisions for pupil transportation were clearly expressed in the statutes rather than being merely implied. This would not necessarily deprive school boards of exercising discretionary authority in dealing with the subject. In fact, the statutes could be explicit in defining school board discretionary authority over pupil transportation within the general laws of the state.

Questions concerning authorization and obligation to provide transportation for pupils would arise less frequently if considerable discretionary authority for issuing regulations were granted to the state board of education. In states where the administrative control and financial support of schools are highly centralized, it would be well for the authority over pupil transportation to be similarly centralized.

One reason why many pupil transportation laws are unsatisfactory is that they were enacted when the needs for such services were different, and have not been amended to meet the conditions of changing times. For example, the recent consolidation of schools has done away largely with the one-room schoolhouse, so that now many children must travel much further to get to school. Moreover, modern transportation has increased hazards of travel for children who walk to school. For these reasons, and the fact that the compulsory school attendance laws are enforced more rigorously, it appears that the furnishing of pupil transportation is more obligatory on the state than formerly.

Regardless of the adequacy of transportational laws, every school administrator and board member should have a thorough knowledge of their provisions and judicial interpretations. Where the law is vague or ambiguous, the board should seek legal interpretation from the attorney general's office. In some instances it may even be advisable to have a test case in order to determine the legality of an act rather than to permit uncertainties to develop into community animosity and costly litigation.

Authorization or prohibition for school boards to expend public funds for the transportation of children to nonpublic schools may be found in the constitutional and statutory provisions of the respective states. This practice does not at present violate provisions of the Federal Constitution. It should be pointed out, however, that the constitutionality of statutory authorization for providing transportation of parochial school children at public expense was upheld by the narrowest majority possible ( 5 to 4 ) in the Supreme Court by the contention that the practice constitutes an "incidental aid" for the benefit of the children involved. If, however, other school costs eventually find their way into the same category, they could conceivably develop such a "substantial aid" as to reverse judicial opinion.

In most states the allocation of liability for personal injuries incurred in pupil transportation is uncertain and unsatisfactory. The simplest remedy would be to abrogate the immunity from liability of school districts so that persons could recover 
damages for injuries resulting from the negligent or improper acts of school officers and employees.

As yet, legislatures appear reluctant to enact laws which would provide for complete abrogation of school district immunity. With the proper motivation from educational organizations and others, however, legislators might be willing to enact legislation which would waive district immunity as applied to pupil transportation. At least the attempt should be made to legalize the purchase of liability insurance for the purpose of paying damages to persons sustaining injuries proximately caused by the negligent operation of motor vehicles used in transporting school children.

The waiving of district immunity and the legalizing of liability insurance are obligations which rest with the legislature. The safety of the children while being transported to and from school, however, is a matter for which the local school officials must assume responsibility. They are responsible for the careful selection of school bus drivers so that the children are not made victims of reckless driving. Moreover, it is their duty to inform bus drivers of the personal liability of the latter in the event of accidents resulting from negligence.

The mere fact that school officials are exempt from legal liability for the tortious acts of their employees imposes upon them a greater moral liability to avoid and eliminate, as much as possible, the dangers involved in pupil transportation. 